\title{
William A. Bussing (1933-2014)
}

\author{
Jorge Cortés ${ }^{1,2} \&$ Arturo Angulo ${ }^{2,3}$ \\ 1. Centro de Investigación en Ciencias del Mar y Limnología (CIMAR), Universidad de Costa Rica, San Pedro, 11501- \\ 2060 San José, Costa Rica; jorge.cortes@ucr.ac.cr \\ 2. Escuela de Biología, Universidad de Costa Rica, San Pedro, 11501-2060 San José, Costa Rica \\ 3. Museo de Zoología, Universidad de Costa Rica, San Pedro, 11501-2060 San José, Costa Rica
}

William Albert Bussing Burhaus, known as Don William, was a professor in the School of Biology at the University of Costa Rica (UCR) from 1966 to 1991, the year in which he retired. He was a Full Professor since 1978. After his retirement he was named Emeritus Professor and continued his work as curator of Ichthyology at the UCR Zoology Museum, until his death in November 2014. As a scholar he worked on the taxonomy, systematics, ecology, zoogeography and evolution of freshwater and marine fishes of Costa Rica and Central America. He published close to 90 papers (see below, list of publications) and described 60 species (see below, list of described species) over his career.

Don William, born on September 27, 1933 in Los Angeles, California in the United States of America, started his university education in the 1950 's. This was interrupted by his military service in Korea, trips to Mexico and in various non-academic and scientific jobs. He took coursework at the University of Guadalajara, Mexico (1958) and the University of Miami, Florida, USA (1961) and he obtained a degree in teaching at the University of Southern California (USC) in 1961, complementing his Bachelors of Arts (AB) from USC in 1960. During those years, 1958-1961, he worked as an assistant on several research projects, including the study "Ecology of the bathypelagic fauna of San Pedro Bay, California", participated in the
William Albert Bussing Burhaus, conocido con Don William, fue profesor de la Escuela de Biología de la Universidad de Costa Rica (UCR) desde 1966 hasta 1991, año en que se acogió a pensión, nombrado Profesor Catedrático en 1978. Posterior a su retiro fue nombrado Profesor Emérito y fungió como curador de la Colección Ictiológica del Museo de Zoología de la UCR hasta su deceso el 17 de noviembre de 2014. Como investigador trabajó en las áreas de taxonomía, sistemática, ecología, zoogeografía y evolución de peces de agua dulce y marinos de Costa Rica y Centro América, publicando cerca de 90 trabajos (ver lista de publicaciones abajo) y describiendo 60 especies (ver lista de especies descritas abajo).

Don William, nacido el 27 de setiembre de 1933, en Los Ángeles, California, Estados Unidos de América (EUA), inició su educación universitaria en la década de 1950. Esta, se vio interrumpida por un periodo de servicio militar en Corea, viajes a México y trabajos en una variedad de puestos no académicos y científicos. Después de atender cursos en la Universidad de Guadalajara, México (1958) y la Universidad de Miami, EUA (1961), obtuvo en 1961 su título de profesorado de la Universidad del Sur de California (USC, por sus siglas en Inglés), complementando el título obtenido en 1960 (Bachiller de Artes - AB, por sus siglas en Inglés) en esa misma institución. Durante estos años (1958-1961) trabajó también como 


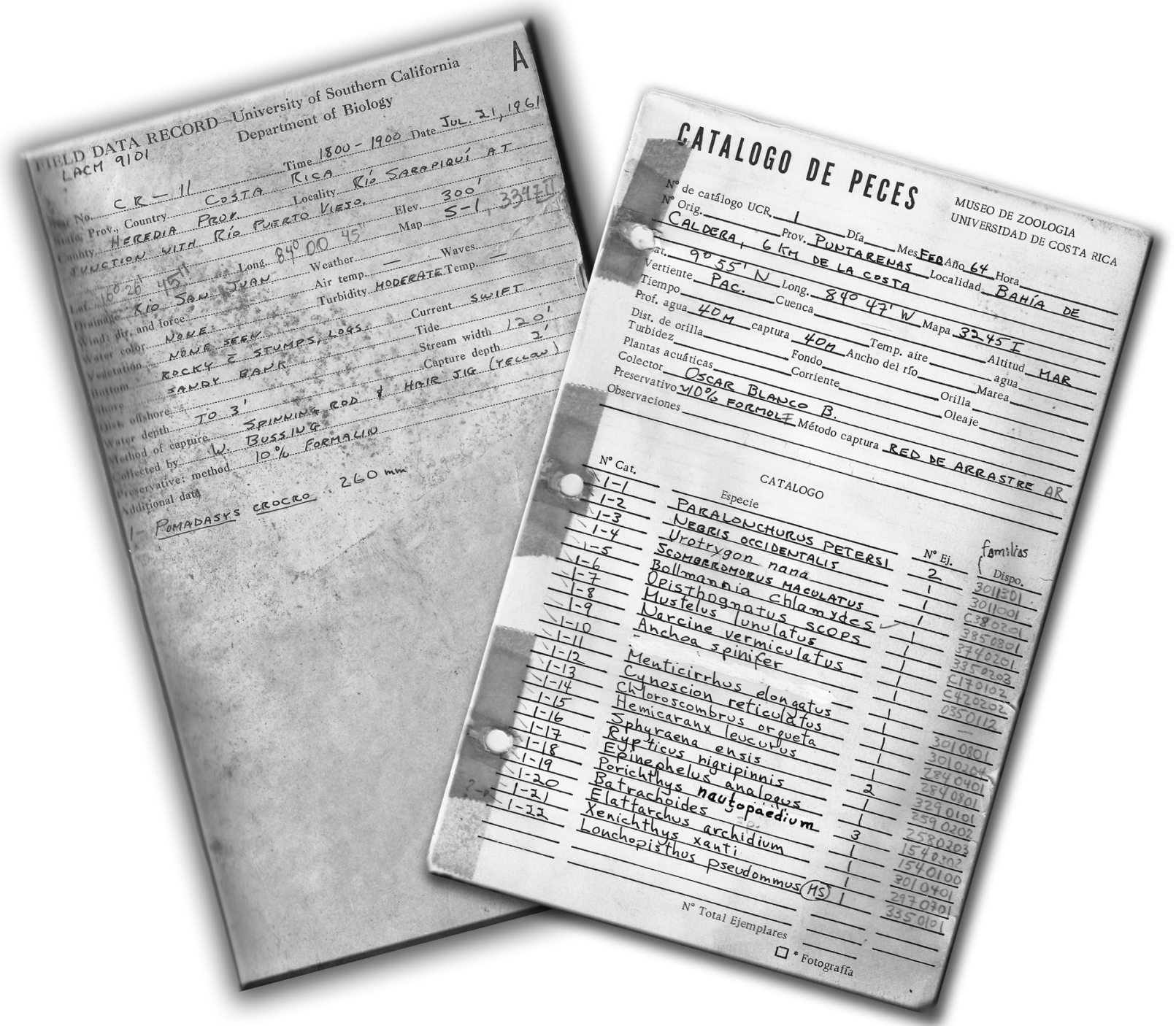

Fig. 1. Primera página de la libreta de campo de William A. Bussing. Muestra tomada el 21 de julio de 1961 donde se unen el Río Sarapiquí con el Río Puerto Viejo, Heredia, Costa Rica.

Fig. 1. First page of the fieldnotes by William A. Bussing. Sample taken on July 211961 at the juntion of the Sarapiquí and Puerto Viejo rivers, Heredia, Costa Rica.

creation and consolidation of the ichthyological collection at the University of Miami, worked for the Los Angeles County Museum (LACM), and taught the course "Natural History of the Vertebrates" at USC.

In 1962 he received an Inter-American Cultural Convention scholarship to study the ecology of the fishes of Río Puerto Viejo, Sarapiquí, in Costa Rica. That year he moved
Fig. 2. Primera página del catálogo de Ictiología del Museo de Zoología de la Universidad de Costa Rica, que data de febrero 1964.

Fig. 2. First page of the Ichthyology Catalogue of the Zoology Museum, University of Costa Rica, from February 1964. 


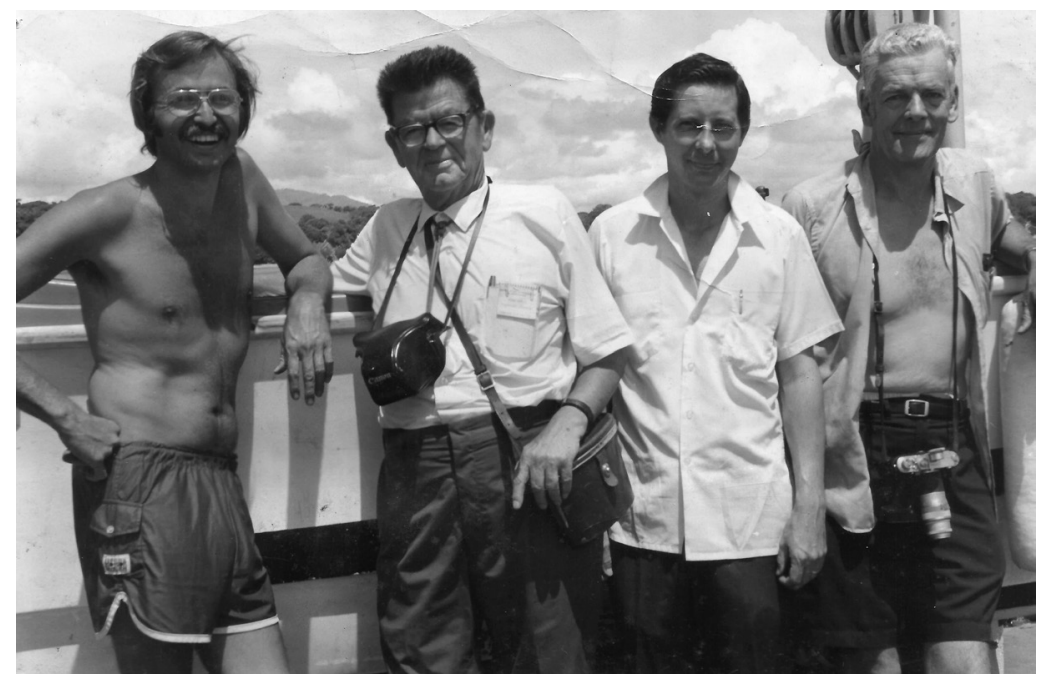

Fig. 3. Robert Lavenberg, Clark Hubbs, William Bussing y otra persona no reconocida en el Golfo de Nicoya, Costa Rica en junio 1973. Participantes de la Reunión 53 de la Sociedad Americana de Ictiólogos y Herpetólogos realizada en la Universidad de Costa Rica a partir del 19 de junio de 1973. Fotógrafo desconocido.

Fig. 3. Robert Lavenberg, Clark Hubbs, William Bussing and unrecognized person; fieldtrip to the Gulf of Nicoya, Costa Rica in June 1973. Participants of the Meeting of the American Society of Ichthyologists and Herpetologists, at the University of Costa Rica, starting on June 19, 1973. Unknown photographer.

to Costa Rica with Jay M. Savage, herpetologist and professor at USC. Between 1962 and 1963, with the support of UCR, Bussing carried out his research on the ichthyofauna of the Río Puerto Viejo in a section that crossed Leslie Holdridge's property (La Selva), that later became the main research station of the Organization for Tropical Studies (OTS). As a result of this research he published his first paper in 1963, the description of a new species, Phallicthys tico, Poeciliidae (endemic to the area). In 1962 he also taught the first Ichthyology course at UCR.

Between 1963 and 1965, under the mentoring of Dr. Savage, Don William did his Master studies at USC. His thesis research was focused on the bathypelagic fishes of the South Eastern Pacific (off the coasts of Perú and Chile). In 1965 he was an assistant in the project, "Fish herbivory at Enewetak Atoll, Marshall Island", that same year he met Myrna Isabel López Sánchez, partner and collaborator for the rest of his life.
En 1962 recibió una beca de la Convención Cultural Inter-Americana para estudiar la ecología de los peces del Río Puerto Viejo, Sarapiquí, en Costa Rica. Ese mismo año hizo efectiva la beca y se desplazó a Costa Rica en compañía de Jay M. Savage, herpetólogo y profesor de la USC. Entre 1962 y 1963, con el apoyo además de la UCR, realizó sus investigaciones sobre la fauna íctica del Río Puerto Viejo en una sección que cruzaba la finca de Leslie Holdridge (La Selva), misma que, posteriormente, pasaría a ser la principal estación de la Organización para Estudios Tropicales (OET). Entre los productos de tal investigación deriva su primera publicación (1963) en la cual describe la especie Phallicthys tico, Poeciliidae (endémica de la zona). En 1962 dictó también el primer curso de Ictiología en la UCR.

Entre 1963 y 1965, bajo la tutela del Dr. Savage, Don William realiza sus estudios de maestría en la USC. Su trabajo de tesis fue sobre los peces batipelágicos del Pacífico Oriental Sur (frente a las costas de Perú y Chile). Para esa época (1965) se desempeña 


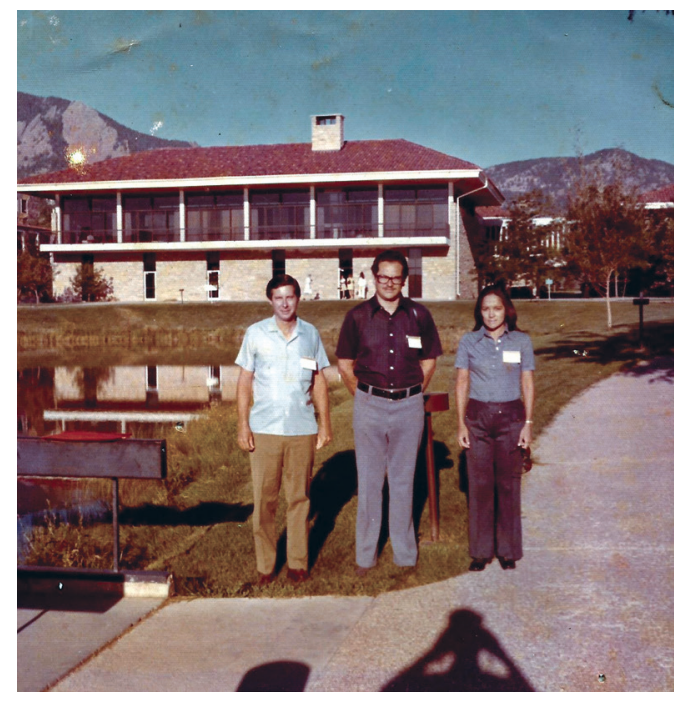

Fig. 4. William A. Bussing, Manuel María Murillo y Myrna I. López, Primer Congreso de Biología Sistemática y Evolutiva, Universidad de Colorado, Boulder, Colorado, 4-12 de agosto de 1973. Fotógrafo desconocido.

Fig. 4. William A. Bussing, Manuel María Murillo and Myrna I. López, First International Congress of Systematic and Evolutionary Biology, University of Colorado, Boulder, Colorado, 4-12 August 1973. Unknown photographer.

In 1966 Bussing was contracted by UCR to teach the Ichthyology course (B-0416) and to develop a research program in marine biology at a national level. During the following years and apart from Ichthyology, he taught General Zoology (B-0214), Marine Biology (B-0302) and Limnology (B-0406).

In 1968 he co-founded, together with Douglas C. Robinson, Myrna I. López Sánchez, Carlos Valerio Gutiérrez, Carlos Villalobos Solé, Jorge Jiménez Jiménez and F. Gary Stiles, the Museo de Zoología (Zoology Museum) at UCR. He was also co-founder in 1979 of the Centro de Investigación en Ciencias del Mar y Limnología (CIMAR, Marine Science and Limnology Research Center) at UCR, together with Manuel María Murillo Castro, Myrna I. López Sánchez, José Antonio Vargas Zamora and Carlos Villalobos Solé. Since its creation, Bussing was part of the research staff of CIMAR, and published the first paper of the Center; the description of another species of

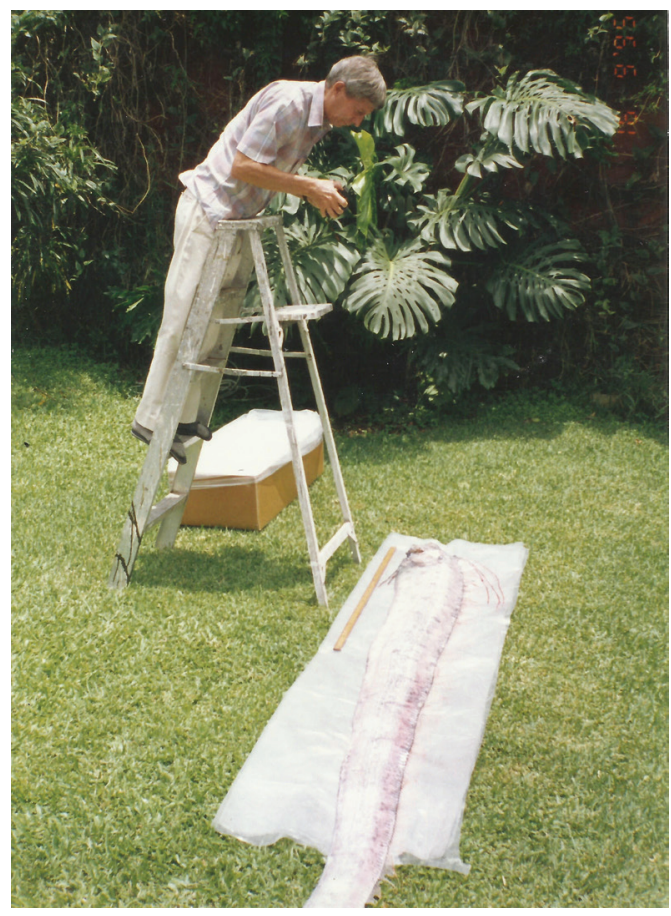

Fig. 5. William Bussing fotografiando un Regalecus, en el jardín de su casa en San Pedro, Costa Rica. Fotografía por Myrna I. López.

Fig. 5. William Bussing photographing a Regalecus, at his house backyard in San Pedro, Costa Rica. Photograph by Myrna I. López.

como asistente del proyecto "Herbivoría de peces en el atolón de Eniwetok, Islas Marshall" y conoce además a Myrna I. López Sánchez, compañera y colaboradora de toda la vida.

En 1966 fue contratado por la UCR para impartir el curso de Ictiología (B-0416) y para desarrollar un programa de investigaciones en biología marina a nivel nacional. En años subsiguientes, dictó, en esa misma casa de enseñanza, además del curso de Ictiología, los cursos de Zoología General (B-0214), Biología Marina (B-0302) y Limnología (B-0406).

En 1968 fue co-fundador, junto con Douglas C. Robinson, Myrna I. López Sánchez, Carlos Valerio Gutiérrez, Carlos Villalobos Solé, Jorge Jiménez Jiménez y F. Gary Stiles, del Museo de Zoología, UCR. También fue cofundador en 1979 del Centro de Investigación en Ciencias del Mar y Limnología (CIMAR) de 
the genus Phallichthys, Family Poeciliidae, of which he described several species.

Don William participated in several expeditions between 1966 and 1985, most of them with his wife Myrna I. López and/or other collaborators. He collected freshwater and marine fishes all over Costa Rica (as well as in other Central American countries). Those specimens are the nucleus of the Ichthyology collection of the Zoology Museum at UCR, located in the basement of the School of Biology. Some specimens were deposited in the collections of the LACM, an institution with which he maintained a close collaboration since 1967 when he was appointed as Associate Researcher. The collection at the Zoology Museum at UCR is among the largest and most complete of the Mesoamerican region, this being one of Bussing's main legacies.

A major product of his collections and detailed museum work is the 1987 book "Bussing, W. A. (1987). Peces de las aguas continentales de Costa Rica/ Freshwater fishes of Costa Rica. Editorial Universidad de Costa Rica, San José, 271 p." That book received the National Prize, "Aquileo J. Echeverría". It is worthwhile mentioning that this is one of the very few science books that have received this honor.

Between 1972 and 1994 he also participated in various scientific expeditions on the Pacific side of Central America and to the islands of Coco and Galápagos, again, most of them together with his wife. Specimens were collected during those expeditions and accumulated important information on the demersal and pelagic ichthyofauna of the coastal and oceanic regions. Together with Myrna López, they published in 1993 the book: "Bussing, W. A., \& López, M. I. (1993). Demersal and Pelagic Inshore Fishes of the Pacific Coast of Lower Central America. An Illustrated Guide. Revista de Biología Tropical (Special Publication): 1-164." and in 2005 another book: "Bussing, W. A., \& López S., M. (2005). Fishes of Cocos Island and Reef Fishes of the Pacific Coast of Lower Central America. Revista de Biología Tropical, 53 (Supplement 2): 1-192.” These are la UCR, junto con Manuel María Murillo Castro, Myrna I. López Sánchez, José Antonio Vargas Zamora y Carlos Villalobos Solé. Desde su fundación, Don William, formó parte del cuerpo de investigadores del CIMAR, publicando además, ese mismo año, el primer trabajo de este centro de investigaciones. Esa publicación fue la descripción de otra especie del género Phallichthys, de la familia Poeciliidae, de la cual describió varias especies.

Entre 1966 y 1985 participó en varias expediciones, la mayoría de ellas en conjunto con su esposa Myrna I. López y/o otros colaboradores, y recolectó peces de agua dulce y marinos en todo el país (así como en otros países de Centro América). Los especímenes recolectados constituyen parte del acervo de la Colección Ictiológica del Museo de Zoología de la UCR, alojada en el sótano de la Escuela de Biología. Algunos ejemplares fueron depositados en la colección del LACM, institución con la cual Don William mantuvo también una estrecha colaboración, recibiendo en 1967 el título de Investigador Asociado. La colección del Museo de Zoología, UCR, cabe destacar, se encuentra actualmente entre las más grandes y completas de la región Mesoamericana, siendo uno de sus principales legados.

Los primeros trabajos de Don William, como profesor e investigador de la UCR fueron sobre taxonomía de peces de agua dulce. Producto del esfuerzo de recolecta antes mencionado y de un minucioso trabajo museográfico y de redacción, se publica en el año de 1987 el libro, "Bussing, W. A. (1987). Peces de las aguas continentales de Costa Rica. Primera edición. Editorial Universidad de Costa Rica, San José, 271 p.", mismo que fue galardonado con el Premio Nacional "Aquileo J. Echeverría". Premio otorgado el mismo año de la publicación del libro. Cabe recalcar, que este trabajo ha sido una de las pocas obras científicas que ha recibido tal reconocimiento.

Entre 1972 y 1994 participa también, nuevamente la mayoría de ellas en conjunto con su esposa Myrna I. López y/o otros colaboradores, en varias expediciones científicas, llevadas a cabo, la mayoría de ellas, en aguas 


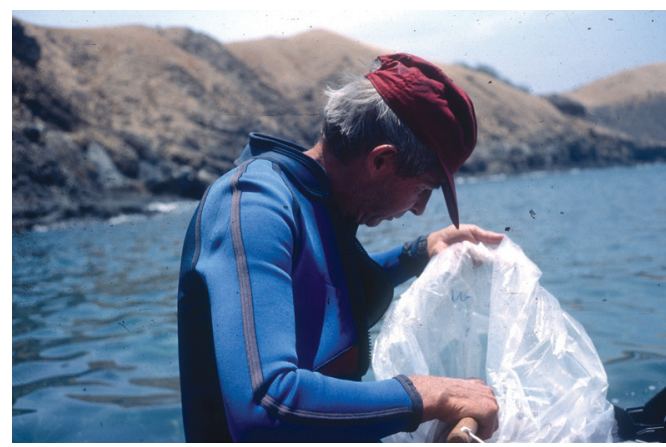

Fig. 6. Don William revisando la colecta en las Islas Murciélago, Área de Conservación Guanacaste, Costa Rica. Abril de 1996. Fotografía por Jorge Cortés.

Fig. 6. Don William checking his collection at Islas Murciélago, Guanacaste Conservation Area, Costa Rica. April 1996. Photograph by Jorge Cortés.

indispensable reference publications for anyone working on the ichthyofauna of the region.

In 1985 he published a seminal paper on freshwater fish biogeography of the Mesoamerican region. Later, in 1990, he was hired by the "Food and Agriculture Organization" (FAO) of the United Nations, to obtain data on diversity and distribution of the ichthyofauna of the Pacific side of Central America and Colombia. This consulting work resulted in publication of several chapters in the FAO guides focused mainly on commercial fishes.

Finally, in 2010, again in collaboration with his wife, they published the book: "Bussing, W. A., \& López, M. I. (2010). Marine Fishes of the Caribbean Coast of Lower Central America: An Illustarted Guide. Revista de Biología Tropical, 58 (Supplement 2): 234 p." Closing a cycle of marine ichthyofaunal research in Costa Rica.

Since 1960, Don William collaborated and was part of the following associations, institutions, commissions and scientific councils: (1) Southern California Academy of Sciences, (2) Sigma Xi Society, (3) American Society of Ichthyologists and Herpetologists, (3) National Council for Scientific and Technological Research of Costa Rica (Consejo Nacional de Investigaciones Científicas y Tecnológicas de Costa Rica, CONICIT), (4) Biologists del Pacífico Centroamericano y en las islas del Coco y Galápagos. En tales expediciones recolecta varios especímenes y reúne importante información sobre la iciofauna demersal y pelágica de la zona costera y de aguas oceánicas de esta región. En colaboración con su esposa, Myrna I. López, publica en 1993 el libro, "Bussing, W., \& López, M. I. (1993). Peces demersales y pelágicos costeros del Pacífico de Centro América Meridional. Guía Ilustrada. Revista de Biología Tropical (Publicación Especial), 1-164.", y en 2005 un segundo libro, "Bussing, W. A., \& López S., M. (2005). Peces de la Isla del Coco y peces arrecifales de la costa Pacífica de América Central meridional. Revista de Biología Tropical, 53 (Suplemento 2), 1-192.", los cuales constituyen obras de consulta obligatoria para todo aquel que quiera trabajar con la ictiofauna de la región.

En 1985 publicó un trabajo fundamental sobre la biogeografía de los peces de agua dulce de la región Mesoamericana. Posteriormente, en 1990, fue contratado por la "Food and Agriculture Organization" (FAO) de la Organización de Naciones Unidas (ONU), para obtener datos sobre la diversidad y distribución de la ictiofauna del Pacífico Centroamericano y Colombiano. Esta consultoría que finalizó con la publicación en 1995 de varios capítulos en un compendio tipo guía práctica sobre la ictiofauna de la región, enfocado principalmente hacia el componente de importancia comercial.

Finalmente, en el 2010, nuevamente en colaboración con su esposa, publica el libro, "Bussing, W. A., \& López, M. I. (2010). Peces costeros del Caribe de Centroamérica Meridional. Guía Ilustrada. Revista de Biología Tropical, 58 (Suplemento 2), 234 p.”. Cerrando con ello un ciclo de investigaciones sobre la ictiofauna marina de Costa Rica.

Desde 1960, Don William colaboró en y formó parte de las siguientes asociaciones, instituciones, comisiones y consejos científicos, (1) Southern California Academy of Sciences, (2) Sigma Xi Society, (3) American Society of Ichthyologists and Herpetologists, (3) Consejo Nacional de Investigaciones Científicas y Tecnológicas de Costa Rica (CONICIT), (4) 
Professional College (Colegio de Biólogos de Costa Rica), (5) Smithsonian Tropical Research Institution (STRI), among others, plus those related to the UCR and USC. In 1998, he was named Honorary Member of the National Academy of Science of Costa Rica.

As noted above, Don William published close to 90 papers and described 60 species of fishes. No other scientist working in Costa Rica has described so many species of vertebrates as Bussing did. He dedicated species to his wife Myrna, his daughter Ilse, and his son Erick, as well as to various colleagues and institutions (see list of species below). As a sign of appreciation several colleagues have dedicated species to Bill Bussing (see below, list of dedicated species).

We hope that this note serves as a well deserved recognition of a notable scientist who was a dear and respectful friend, colleague and mentor. We will always be grateful to him and keep him in our memory.

\section{ACKNOWLEDGMENTS}

We thank Myrna López and Ana Rosa Ramírez for their help and photographs, and Peter J. Auster for the review of the English version.
Colegio de Biólogos de Costa Rica, (5) Instituto Smithsonian de Investigaciones Tropicales (STRI), entre otros, además de sus relaciones con la UCR y la USC. En 1998, cabe destacar, fue declarado Miembro Honorario de la Academia Nacional de Ciencias de Costa Rica.

Como se mencionó anteriormente, Don William publicó más de 80 trabajos científicos (ver lista de publicaciones abajo) y describió unas 60 especies de peces. Ningún otro científico, trabajando en Costa Rica, ha descrito más especies de animales vertebrados que Don William. El dedicó especies a su esposa, a su hija, Ilse, y a su hijo, Erick, así como a varios otros colegas e instituciones (ver lista de especies abajo). Como muestra de aprecio diferentes colegas también le dedicaron varias especies (ver lista de especies abajo).

Esperamos que esta nota sea un merecido reconocimiento póstumo para un notable científico, quien fuera nuestro querido y respetado amigo, colega y mentor, del que siempre estaremos agradecidos y al que esperamos mantener en el más grato lugar de nuestra memoria.

\section{Publicaciones de (Publications by) William A. Bussing}

01. Bussing, W. A. (1963). A new poeciliid fish, Phallichthys tico from Costa Rica. Contributions in Science (Los Angeles), No. 77, 1-13.

02. Bussing, W. A. (1965). Biology of the Antarctic Seas 2. Studies of the midwater fishes of the Peru-Chile Trench. Antarctic Research Series, 5, 185-227.

03. Bussing, W. A., \& Bussing, M. I. (1966). Antarctic Scopelarchidae, a new fish of the genus Benthalbella and the distribution of B. elongata (Norman). Bulletin of the
Southern California Academy of Sciences, 65, 53-64.

04. Price, C. E., \& Bussing, W. A. (1967). Monogenean parasites of Costa Rican fishes. Part 1. Descriptions of two new species of Cleidodiscus Mueller, 1934. Rivista di Parassitologia, 27, 81-86.

05. Bussing, W. A. (1967). New species and new records of Costa Rican freshwater fishes with a tentative list of species. Revista de Biologia Tropical, 14, 205-249.

06. Villa, J. D., \& Bussing, W. A. (1967). Indicaciones generales para preservar peces, anfibios y reptiles. O'Bios, Revista de Ciencias Naturales, 2, 21-24. 
07. Price, C. E., \& Bussing, W. (1968). Monogenean parasites of Costa Rican fishes. II. Proposal of Palombitrema heteroancistrium n. gen., n. sp. Proceedings of the Helminthological Society of Washington, 35, 54-57.

08. Bussing, W. A. (1968). Zoología General. Guía de Laboratorio. Editorial Universidad de Costa Rica, Serie Textos N. 161, 130 p.

09. Bussing, W. A. (1969). Familias de Peces Marinos Costarricenses. Editorial Universidad de Costa Rica, Serie Ciencias Naturales, N. 6, 39 p.

10. Bussing, W. A. (1970). Two new species of catfishes of the genera Nannorhamdia and Imparales (Family Pimelodidae) from Central America. Los Angeles County Museum Contributions in Science, 196, 1-11.

11. Bussing, W. A., \& Roberts, T. R. (1971). Rediscovery of the glandulocaudine fish Pterobrycon and the hypothetical significance of its spectacular humeral scales (Pisces, Characidae). Copeia, 1971, 179-181.

12. Bussing, W. A. (1972). Halichoeres aestuaricola, a replacement name for the tropical Eastern Pacific labrid fish, lridio bimaculata Wilson, with a redescription based on new material. Brenesia, 1, 3-8.

13. Bussing, W. A. (1972). Recolonization of a population of supratidal fishes at Eniwetok Atoll, Marshall Islands. Atoll Research Bulletin, 154, 1-4.

14. Bussing, W. A. (1974). Two new species of cichlid fishes, Cichlasoma sajica and C. diquis, from southeastern Costa Rica. Revista de Biología Tropical, 22, 29-49.

15. Bussing, W. A. (1974). Pterobrycon myrnae, a remarkable new glandulocaudine characid fish from Costa Rica. Revista de Biología Tropical, 22, 135-159.

16. Bussing, W. A., \& Martin, M. (1975). Systematic status, variation and distribution of four Middle American cichlid fishes belonging to the Amphilophus species group, genus Cichlasoma. Los Angeles County Museum Contributions in Science, 269, $1-41$.
17. Bussing, W. A. (1975). Utilidad de los recursos pesqueros nacionales. Revista Universidad de Costa Rica, 41, 17-21.

18. Bussing, W. A. (1976). Taxonomy and biological aspects of the Central American cichlid fishes Cichlasoma sieboldii and C. tuba. Revista de Biología Tropical, 23, 189- 211.

19. Bussing, W. A. (1976). Geographic distribution of the San Juan icthyiofauna of Central America with remarks on its origin and ecology. Pp. 157-175. In, T. B. Thorson (Ed.). Investigations of the Ichthyiofauna of Nicaraguan Lakes. American Society of Ichthyologists and Herpetologists and School of Life Sciences, University of Nebraska-Lincoln.

20. Bussing, W., \& López S., M. (1977). Distribución y aspectos ecológicos de los peces de las cuencas hidrográficas de Arenal, Bebedero y Tempisque, Costa Rica. Revista de Biología Tropical, 25, 13-37.

21. Bussing, W. A., \& López S., M. I. (1977). Guentherus altivela Osorio, the first ateleopodid fish reported from the eastern Pacific Ocean. Revista de Biología Tropical, 25, 179-190.

22. Bussing, W. A. (1978). Taxonomic status of the atherinid fish genus Melaniris in Lower Central America, with descriptions of three new species. Revista de Biología Tropical, 26, 391-413.

23. Bussing, W. A. (1979). A new fish of the genus Phallichthys (Family Poeciliidae) from Costa Rica. Los Angeles County Museum Contributions to Science, 301,1-8.

24. Bussing, W. A. (1980). Status of the cyprionodont genus Rivulus in Costa Rica, with descriptions of new endemic species. Brenesia, 17, 327-363.

25. Bussing, W. A. (1980). Lioproma fasciatum, a new serranid fish and only known member of the genus from the tropical eastern Pacific Ocean. Revista de Biología Tropical, 28, 147-151.

26. Constantz, G. D., Bussing, W. A. \& Saul, W. G. (1981). Freshwater fishes of Corcovado National Park, Costa Rica. 
Proceedings of the Academy of Natural Sciences of Philadelphia, 133, 15-19.

27. Bussing, W. A. (1981). Elacatinus janssi, a new gobiid fish from Costa Rica. Revista de Biología Tropical, 29, 251-256.

28. López, M., \& Bussing, W. A. (1982). Lista provisional de los peces marinos de la costa Pacífica de Costa Rica. Revista de Biología Tropical, 30, 5-26.

29. Bussing, W. A. (1983). A new tropical eastern Pacific labrid fish, Halichoeres discolor endemic to Isla del Coco. Revista de Biología Tropical, 31, 19-23.

30. Bussing, W. A. (1983). Evermannia erici, a new burrowing gobiid fish from the Pacific coast of Costa Rica. Revista de Biología Tropical, 31, 125-131.

31. Bartels, C. E., Price, K. S, López, M. I., \& Bussing, W. A. (1983). Occurrence, distribution, abundance and diversity of fishes in the Gulf of Nicoya, Costa Rica. Revista de Biología Tropical, 31, 75-101.

32. Bartels, C., Price, K. S., López-Bussing, M., \& Bussing, W. (1984). Ecological assessment of finfish as indicators of habitats in the Gulf of Nicoya, Costa Rica. Hydrobiologia, 112, 197-207.

33. Bussing, W. A. (1985). Patterns of distribution of the ichthyofauna, Pp. 453-473. In, G. Stehli \& D. Webb (Eds.). The Great American Biotic Interchange. Plenum Press, New York.

34. Bussing, W. A. (1985). Roeboides ilseae, a new scale-eating characid fish from Costa Rica. Revista de Biología Tropical, 33, 45-50.

35. Bussing, W. A. (1987). Los peces de la Familia Labridae de la costa Pacífica de Costa Rica. Revista de Biología Tropical, 33, 81-98.

36. Gocke, K., Bussing, W., \& Cortés, J. (1987). Morphometric and basic limnological properties of the Laguna de Río Cuarto, Costa Rica. Revista de Biología Tropical, 35, 277-285.

37. Bussing, W. A. (1987). Peces de las aguas continentales de Costa Rica. Primera edición. Editorial Universidad de Costa Rica, San José, Costa Rica. 271 p.

38. Bussing, W. A. (1988). A new fish, Brachyrhaphis roseni (Poeciliidae) from Costa Rica and Panamá. Revista de Biología Tropical, 36, 81-87.

39 Guzmán, H. M., Campos, J., Gamboa, C., \& Bussing, W. A. (1988). Un arrecife artificial de llantas, Su potencial para el manejo de pesquerías. Anales del Instituto de Ciencias del Mar y Limnología, Universidad Nacional Autónoma de México, 15, 249-254.

40. Bussing, W. A. (1989). Cichlasoma loisellei, a new Nandopsis group cichlid fish from Central America. Revista de Biología Tropical, 37, 153-161.

41. Bussing, W. A. (1990). New species of gobiid fishes of the genera Lythrypnus, Elacatinus and Chriolepis. Revista de Biología Tropical, 38, 99-118.

42. Gocke, K., Bussing, W. A., \& Cortés, J. (1990). The annual cycle of primary productivity in Laguna de Río Cuarto, a volcanic lake (maar) in Costa Rica. Revista de Biología Tropical, 38, 387-394.

43. Bussing, W. A. (1991). A new genus and two new species of tripterygiid fishes from Costa Rica. Revista de Biología Tropical, 39, 77-85.

44. Bussing, W. A. (1991). A new species of eastern Pacific moray eel (Pisces, Muraenidae). Revista de Biología Tropical, 39, 97-102.

45. Bussing, W. A. (1993). Pomadasys empherus, a new species of haemulid fish from the tropical eastern Pacific. Revista de Biología Tropical, 41, 245-251.

46. Bussing, W. A. (1993). Fish communities and environmental characteristics of a tropical rain forest river in Costa Rica. Revista de Biología Tropical, 41, 791-809.

47. Bussing, W. A., \& López, M. I. (1993). Peces demersales y pelágicos costeros del Pacífico de Centro América Meridional. Guía Ilustrada. / Demersal and Pelagic Inshore Fishes of the Pacific Coast of Lower Central America. An Illustrated Guide. 
Revista de Biología Tropical (Publicación Especial), 1-164.

48. Bussing, W. A. (1994). Ecological aspects of the fish community. Pp. 195-198. In, L. McDade, K. Bawa, H. A. Hespenheide, \& G. S. Hartshorn (Eds.). La Selva, Ecology and Natural History of a Tropical Rainforest. University of Chicago Press, Chicago.

49. Krupp, F., \& Bussing, W. A. (1995). Quimeras. Chimaeridae. Quimeras ñatas. Rhinochimaeridae. Quimeras picudas. Pp. 791-798. In F. Krupp, W. Schneider, C. Sommer, K. E. Carpenter, \& V. H. Niem (Eds.). Guía FAO para la identificación de especies para los fines de la Pesca. Pacifico Centro-Oriental. Organización de las Naciones Unidas para la Agricultura y la Alimentación (FAO). Roma, Italia.

50. Kailola, P. J., \& Bussing, W. A. (1995). Ariidae. Bagres marinos. Pp. 860-886. In F. Krupp, W. Schneider, C. Sommer, K. E. Carpenter, \& V. H. Niem (Eds.). Guía FAO para la identificación de especies para los fines de la Pesca. Pacífico CentroOriental. Organización de las Naciones Unidas para la Agricultura y la Alimentación (FAO). Roma, Italia.

51. Bussing, W. A. (1995). Ateleopodidae. Ateleopódidos, trompas dulces. Pp. 887888. In F. Krupp, W. Schneider, C. Sommer, K. E. Carpenter, \& V. H. Niem (Eds.). Guía FAO para la identificación de especies para los fines de la Pesca. Pacifico Centro-Oriental. Organización de las Naciones Unidas para la Agricultura y la Alimentación (FAO). Roma, Italia.

52. Bussing, W. A. (1995). Balistidae. Pejepuercos, calafates, gatillos. Pp. 905-909. In, F. Krupp, W. Schneider, C. Sommer, K. E. Carpenter, \& V. H. Niem (Eds.). Guía FAO para la identificación de especies para los fines de la Pesca. Pacifico Centro-Oriental. Organización de las Naciones Unidas para la Agricultura y la Alimentación (FAO). Roma, Italia.

53. Bussing, W. A.(1995). Centropomidae. Róbalos. Pp. 987-995. In, F. Krupp, W.
Schneider, C. Sommer, K. E. Carpenter, \& V. H. Niem (Eds.). Guía FAO para la identificación de especies para los fines de la Pesca. Pacífico Centro-Oriental. Organización de las Naciones Unidas para la Agricultura y la Alimentación (FAO). Roma, Italia.

54. Bussing, W. A. (1995). Cirrhitidae. Chinos, halcones. Pp. 1007-1010. In, F. Krupp, W. Schneider, C. Sommer, K. E. Carpenter, \& V. H. Niem (Eds.). Guía FAO para la identificación de especies para los fines de la Pesca. Pacífico Centro-Oriental. Organización de las Naciones Unidas para la Agricultura y la Alimentación (FAO). Roma, Italia.

55. Bussing, W. A. (1995). Gerreidae. Mojarras. Pp. 1114-1128. In, F. Krupp, W. Schneider, C. Sommer, K. E. Carpenter, \& V. H. Niem (Eds.). Guía FAO para la identificación de especies para los fines de la Pesca. Pacífico Centro-Oriental. Organización de las Naciones Unidas para la Agricultura y la Alimentación (FAO). Roma, Italia.

56. Bussing, W. A. (1995). Monacanthidae. Cachúas, lijas. Pp. 1278-1280. F. Krupp, W. Schneider, C. Sommer, K. E. Carpenter, \& V. H. Niem (Eds.). Guía FAO para la identificación de especies para los fines de la Pesca. Pacífico Centro-Oriental. Organización de las Naciones Unidas para la Agricultura y la Alimentación (FAO). Roma, Italia.

57. Bussing, W. A. (1995). Synodontidae. Lagartos. Pp. 1625-1628. In, F. Krupp, W. Schneider, C. Sommer, K. E. Carpenter, \& V. H. Niem (Eds.). Guía FAO para la identificación de especies para los fines de la Pesca. Pacífico Centro-Oriental. Organización de las Naciones Unidas para la Agricultura y la Alimentación (FAO). Roma, Italia.

58. Bussing, W. A. (1995). Tetraodontidae. Tamboriles, tamborines, botetes, peces globo, corrotuchos. Pp. 1629-1637. In, F. Krupp, W. Schneider, C. Sommer, K. E. Carpenter, \& V. H. Niem (Eds.). Guía FAO 
para la identificación de especies para los fines de la Pesca. Pacífico CentroOriental. Organización de las Naciones Unidas para la Agricultura y la Alimentación (FAO). Roma, Italia.

59. Bussing, W. A. (1995). Triglidae. Rubios. Pp. 1643-1648. In, F. Krupp, W. Schneider, C. Sommer, K. E. Carpenter, \& V. H. Niem (Eds.). Guía FAO para la identificación de especies para los fines de la Pesca. Pacifico Centro-Oriental. Organización de las Naciones Unidas para la Agricultura y la Alimentación (FAO). Roma, Italia.

60. Bussing, W. A. (1995). Uranoscopidae. Miracielos, miraestrellas. Pp. 1649-1650. In, F. Krupp, W. Schneider, C. Sommer, K. E. Carpenter, \& V. H. Niem (Eds.). Guía FAO para la identificación de especies para los fines de la Pesca. Pacífico Centro-Oriental. Organización de las Naciones Unidas para la Agricultura y la Alimentación (FAO). Roma, Italia.

61. Bussing, W. A., \& López, M. I. (1996). Fishes collected during the RV Victor Hensen Expedition (1993/1994). Revista de Biología Tropical, 44 (Suplemento 3), 183-186.

62. Bussing, W. A. (1996). A new species of eleotridid, Eleotris tecta, from Pacific slope streams of tropical America (Pisces, Eleotrididae). Revista de Biología Tropical, 44, 251-257.

63. Bussing, W. A. (1996). Sicydium adelum, a new species of gobiid fish (Pisces, Gobiidae) from Atlantic slope streams of Costa Rica. Revista de Biología Tropical, 44, 819-825.

64. Bussing, W. A. (1996). Book review, Fishes of the Tropical Eastern Pacific by G. R. Allen, D. R. Robertson. Copeia, 1996, 234-235.

65. Walker, H. J., \& Bussing W. A. (1996). Two new pufferfish of the genus Sphoeroides (Tetraodontidae) from the Eastern Pacific. Copeia, 1996, 677-684.

66. Bussing, W. A. (1997). Chriolepis atrimelum (Gobiidae) a new species of gobiid fish from Isla del Coco, Costa Rica. Revista de Biología Tropical, 45, 1547-1552.

67. Bussing, W. A. (1998). Gymnothorax phalarus, a new eastern Pacific moray eel (Pisces, Muranidae). Revista de Biología Tropical, 46, 439-446.

68. Bussing, W. A. (1998). Peces de las aguas continentales de Costa Rica. Segunda edición. Editorial Universidad de Costa Rica, San José, Costa Rica. 468 p.

69. López, M. I., \& Bussing, W. A. (1998). Urotrygon cimar, a new eastern Pacific stingray (Pisces, Urolophidae). Revista de Biología Tropical, 46 (Suplemento 6), 271-277.

70. Bussing, W. A. (2001). Ptereleotris carina$t a$, a new species of hovering goby (Perciformes, Microdesmidae) from the tropical eastern Pacific. Revista de Biología Tropical, 49 (Supplement 1), 133-139.

71. Bussing, W. A., \& Lavenberg, R. J. (2003). Four new species of eastern tropical Pacific jawfishes (Opistognathus, Opistognathidae). Revista de Biología Tropical, 51, 529-550.

72. Bussing, W. A., \& López, M. I. (2005). Peces de la Isla del Coco y peces arrecifales de la costa Pacífica de América Central meridional. / Fishes of Cocos Island and Reef Fishes of the Pacific Coast of Lower Central America. Revista de Biología Tropical, 53 (Suplemento 2), 5-192.

73. Abell, R., Thieme, M. L., Revenga, C., Bryer, M., Kottelat, M., Bogutskaya, N. Coad, B., Mandrak, N., Contreras-Balderas, S, Bussing, W. A., Stiassny, M. L. J., Skelton, P., Allen, G. R., Unmack, P, Naseka, A., Sindorf, R. N., Robertson, J., Armijo, E., Higgins, J. V., Heibel, T. J., Wikramanayake, E., Olson, D., López, H. L., Reis, R. E., Lundberg, J. G., SabajPérez, M. H., \& Petry, P. (2008). Freshwater ecoregions of the world, A new map of biogeographic units for freshwater biodiversity conservation. BioScience, 58, 403-405.

74. Herrera-Vásquez, J., Bussing, W. A., \& Villalobos, F. (2008). Panbiogeographical 
analysis of Costa Rican freshwater fishes. Revista de Biología Tropical, 56, 165-170.

75. Bussing, W. A. (2008). A new species of poeciliid fish, Poeciliopsis santaelena, from Peninsula Santa Elena, Área de Conservación Guanacaste, Costa Rica. Revista de Biología Tropical, 56, 829-839.

76. Bussing, W. A. (2008). Astyanax cocibolca, a new characid (Pisces, Ostariophysi) from Lake Nicaragua, Central America. Revista de Biología Tropical, 56, 1361-1370.

77. Bussing, W. A., \& López, M. (2009). Marine fishes. Texto (Text), Pp. 453-458, List de especies, Disco Compacto (Species List in Compact Disc) Pp. 412-473. In, I. S. Wehrtmann \& J. Cortés (Eds.). Marine Biodiversity of Costa Rica, Central America. Monographiae Biologicae, 86. Springer + Business Media B.V., Berlín.

78. Bussing, W. A., \& López, M. I. (2010). Peces costeros del Caribe de Centroamérica Meridional / Marine Fishes of the Caribbean Coast of Lower Central America. Revista de Biología Tropical, 58 (Suplemento 2), $234 \mathrm{p}$.

79. Bussing, W. A. (2010). A new fish, Peristedion nesium (Scorpaeniformes, Peristediidae) from Isla del Coco, Costa Rica. Revista de Biología Tropical, 58, 1149-1156.

80. Angulo, A., Garita-Alvarado, C. A., Bussing, W. A., \& López, M. I. (2013). Annotated checklist of the freshwater fishes of continental and insular Costa Rica, additions and nomenclatural revisions. Check List, 9, 987-1019.

81. Angulo, A., López, M. I., Bussing, W. A., \& Murase, A. (2014). Records of chimaeroid fishes (Holocephali, Chimaeriformes) from the Pacific coast of Costa Rica, with the description of a new species of Chime$r a$ (Chimaeridae) from the eastern Pacific Ocean. Zootaxa, 3861, 554-574.

82. Murase, A., Angulo, A., Miyazaki, Y., Bussing, W. A., \& López, M. I. (2014). Marine and estuarine fish diversity in the inner Gulf of Nicoya, Pacific coast of
Costa Rica, Central America. Check List, 10, 1401-1413.

83. Del Moral-Flores, L. F., Angulo, A., López, M. I., \& Bussing, W. A. (2015). Nueva especie del género Urobatis (Myliobatiformes, Urotrygonidae) del Pacífico oriental tropical. Revista de Biología Tropical, 63, 501-514.

84. Angulo, A., Molina-Arias, A., Murase, A., Miyazaki, Y., Bussing, W. \& López, M. 2015. Fishes from the Tusubres River basin, Pacific coast, Costa Rica: checklist, identification key and photographic album. Check List, 11 (Article 1666), 1-15.

85. Angulo, A., Bussing, W. A., \& López, M. I. (2015). Occurrence of the tripodfish Bathypterois ventralis (Aulopiformes, Ipnopidae) in the Pacific coast of Costa Rica. Revista Mexicana de Biodiversidad, 86, 546-549.

86. Angulo, A., López, M. I., Bussing, W. A., Ramírez-Coghi, A. R., \& Arias-Godínez, G. (En prensa). Colección Ictiológica del Museo de Zoología de la Universidad de Costa Rica. In, L.F. Del Moral-Flores, J. A. Martínez-Pérez, \& A. J. RamírezVillalobos. Colecciones ictiológicas de Latinoamérica. Editorial de la Facultad de Estudios Superiores Iztacala, Universidad Nacional Autónoma de México, México D.F., México.

87. Angulo, A., Arias-Godínez, G., López, M. I., \& Bussing, W. A. (En prensa). Catálogo de material tipo depositado en la colección ictiológica del Museo de Zoología de la Universidad de Costa Rica. In, L. F. Del Moral-Flores, J. A. Martínez-Pérez, \& A. J. Ramírez-Villalobos. Colecciones ictiológicas de Latinoamérica. Editorial de la Facultad de Estudios Superiores Iztacala, Universidad Nacional Autónoma de México, México D.F., México.

\section{Especies descritas por}

(Species described by) William A. Bussing

01. Phallichthys tico, Familia Poeciliidae (referencia-reference, N. 01) 
02. Binghamichthys aphos, Familia Alepocephalidae (referencia-reference, N. 02)

03. Lampanyctus iselinoides, Familia Myctophidae (referencia-reference, N. 02)

04. Melanostigma bathium, Familia Zoarcidae (referencia-reference, N. 02)

05. Benthalbella macropinna, Familia Scopelarchidae (referencia-reference, N. 03)

06. Brachyrhaphis holdridgei Familia Poeciliidae (referencia-reference, N. 05)

07. Hyphessobrycon savagei, Familia Characidae, (referencia-reference, N. 05)

08. Piabucina boruca, Familia Lebiasininae (referencia-reference, N. 05)

09. Poeciliopsis paucimaculata, Familia Poeciliidae (referencia-reference, N. 05)

10. Pseudocheirodon terrabae, Familia Characidae (referencia-reference, N. 05)

11. Nannorhamdia lineata, Familia Heptapteridae (referencia-reference, N. 10)

12. Imparales panamensis, Familia Heptapteridae (referencia-reference, N. 10)

13. Halichoeres aestuaricola, Familia Labridae (referencia-reference, N. 12)

14. Cichlasoma diquis, Familia Cichlidae (referencia-reference, N. 14)

15. Cichlasoma sajica, Familia Cichlidae (referencia-reference, N. 14)

16. Pterobrycon myrnae, Familia Characidae (referencia-reference, N. 15)

17. Melaniris hubbsi, Familia Atherinopsidae (referencia-reference, N. 22)

18. Melaniris jiloaensis, Familia Atherinopsidae (referencia-reference, N. 22)

19. Melaniris milleri, Familia Atherinopsidae (referencia-reference, N. 22)

20. Phallichthys quadripunctatus, Familia Poeciliidae (referencia-reference, N. 23)

21. Rivulus fuscolineatus, Familia Rivulidae (referencia-reference, N. 24)

22. Rivulus glaucus, Familia Rivulidae (referencia-reference, N. 24)

23. Rivulus rubripunctatus, Familia Rivulidae (referencia-reference, N. 24)

24. Rivulus siegfriedi, Familia Rivulidae (referencia-reference, N. 24)

25. Rivulus uroflammeus, Familia Rivulidae (referencia-reference, N. 24)
26. Liopropoma fasciatum, Familia Serranidae (referencia-reference, N. 25)

27. Elacatinus janssi, Familia Gobiidae (referencia-reference, N. 27)

28. Halichoeres discolor, Familia Labridae (referencia-reference, N. 29)

29. Evermannia erici, Familia Gobiidae (referencia-reference, N. 30)

30. Roeboides ilseae, Familia Characidae (referencia-reference, N. 31)

31. Brachyrhaphis roseni, Familia Poeciliidae (referencia-reference, N. 38)

32. Cichlasoma loisellei, Familia Cichlidae (referencia-reference, N. 40)

33. Chriolepis dialepta, Familia Gobiidae (referencia-reference, N. 41)

34. Chriolepis cuneata, Familia Gobiidae (referencia-reference, N. 41)

35. Elacatinus inornatus, Familia Gobiidae (referencia-reference, N. 41)

36. Elacatinus nesiotes, Familia Gobiidae (referencia-reference, N. 41)

37. Lythrypnus alphigena, Familia Gobiidae (referencia-reference, N. 41)

38. Lythrypnus cobalus, Familia Gobiidae (referencia-reference, N. 41)

39. Lythrypnus insularis, Familia Gobiidae (referencia-reference, N. 41)

40. Lythrypnus lavenbergi, Familia Gobiidae (referencia-reference, N. 41)

41. Axoclinus cocoensis, Familia Tripterygiidae (referencia-reference, N. 42)

42. Lepidonectes clarkhubbsi, Familia Tripterygiidae (referencia-reference, N. 42)

43. Uropterygius versutus, Familia Muraenidae (referencia-reference, N. 44)

44. Pomadasys empherus, Familia Haemulidae (referencia-reference, N. 45)

45. Eleotris tecta, Familia Eleotridae (referencia-reference, N. 62)

46. Sicydium adelum, Familia Gobiidae (referencia-reference, N. 63)

47. Sphoeroides rosenblatti, Familia Tetraodontidae (referencia-reference, N. 65)

48. Chriolepis atrimelum, Familia Gobiidae (referencia-reference, N. 66)

49. Gymnothorax phalarus, Familia Muraenidae (referencia-reference, N. 67) 
50. Urotrygon cimar, Familia Urotrygonidae (referencia-reference, N. 69)

51. Ptereleotris carinata, Familia Microdesmidae (referencia-reference, N. 70)

52. Opistognathus brochus, Familia Opistognathidae (referencia-reference, N. 71)

53. Opistognathus fossoris, Familia Opistognathidae (referencia-reference, N. 71)

54. Opistognathus smithvanizi, Familia Opistognathidae (referencia-reference, N. 71)

55. Opistognathus walkeri, Familia Opistognathidae (referencia-reference, N. 71)

56. Poeciliopsis santaelena, Familia Poeciliidae (referencia-reference, N. 75)

57. Astyanax cocibolca, Familia Characidae (referencia-reference, N. 76)

58. Peristedion nesium, Familia Peristediidae (referencia-reference, N. 79)

59. Chimaera orientalis, Familia Chimaeridae (referencia-reference, N. 81)

60. Urobatis pardalis, Familia Urotrygonidae (referencia-reference, N. 83)

\section{Especies dedicadas a}

(Species dedicated to) William A. Bussing

01. Platygillellus bussingi, Familia Dactyloscopidae (referencia-reference: Dawson, C. E. (1974). Studies on eastern Pacific sand stargazers (Pisces, Dactyloscopidae) 1. Platygillelus new genus, with descriptions of new species. Copeia, 1974, 39-55.)

02. Umbrina bussingi, Familia Sciaenidae (referencia-reference: López S., M. I.
(1980). Umbrina bussingi, a new sciaenid fish from the tropical eastern Pacific Ocean. Revista de Biologia Tropical, 28, 203-208.)

03. Talismania bussingi, Familia Alepocephalidae (referencia-reference: Sazonov, Y. I. (1989). A new species of the genus Talismania Goode et Bean (Alepocephalidae) from the southeast Pacific. Journal of Ichthyology, 29, 83-87.)

04. Amphilophus bussingi, Familia Cichlidae (referencia-reference: Loiselle, P. V. (1997). Diagnoses of two new cichlids from the Rio Sixaola Drainage, Costa Rica. Buntbarsche Bulletin, 180, 1-8.)

05. Gunterichthys bussingi, Familia Bythitidae (referencia-reference: Møller, P. R., Schwarzhans, W., \& Nielsen, J. G. (2004). Review of the American Dinematichthyini (Teleostei, Bythitidae). Part I. Dinematichthys, Gunterichthys, Typhliasina and two new genera. Aqua, Journal of Ichthyology and Aquatic Biology, 8, 141-192.)

06. Roeboides bussingi, Familia Characidae (referencia-reference: Matamoros, W. A., Chakrabarty, P., Angulo, A., Garita-Alvardo, C. A., \& McMahan, C. D. (2013). A new species of Roeboides (Teleostei, Characidae) from Costa Rica and Panama, with a key to the middle American species of the genus. Neotropical Ichthyology, 11, 285-290.) 